REVISTA de

PEDAGOGIE

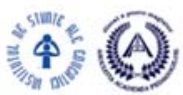

JOURNAL of

PEDAGOGY

http://revped.ise.ro

Print ISSN 0034-8678; Online ISSN: 2559 - 639X

\title{
FORMATIVE ASSESSMENT AS ASSESSMENT FOR \\ LEARNING DEVELOPMENT
}

EVALUAREA FORMATIVĂ CA EVALUARE PENTRU DEZVOLTAREA ÎNVĂȚĂRII

\section{Lucian VOINEA}

Journal of Pedagogy, 2018 (1), 7 - 23

https://doi.org/10.26755/RevPed/2018.1/7

The online version of this article can be found at: http://revped.ise.ro/category/2018-en/

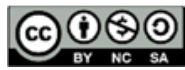

This work is licensed under the Creative Commons Attribution-NonCommercial-ShareAlike 4.0 International License.

To view a copy of this license, visit http://creativecommons.org/licenses/by-nc-sa/4.0/ or send a letter to Creative Commons, PO Box 1866, Mountain View, CA 94042, USA.

Published by:

\section{INSTITUTUL DE ȘTIINTTE ALE EDUCAȚIEI}

http://www.ise.ro/

Further information about Revista de Pedagogie - Journal of Pedagogy can be found at:

Editorial Policy: http://revped.ise.ro/editorial-policy/

Author Guidelines: http://revped.ise.ro/the-writer-guide-2/ 


\title{
STUDII TEORETICE
}

\section{FORMATIVE ASSESSMENT AS ASSESSMENT FOR LEARNING DEVELOPMENT}

\author{
Institute of Educational Sciences \\ Bucharest, Romania \\ lucian.voinea@ise.ro
}

\begin{abstract}
The article is a plea for the use of formative assessment - with a focus on the role of feedback - in order to develop students' learning, including Learning to learn competence. We deal, mainly, with such aspects related to making learning visible for the students: learning goals, learning success criteria, assessment of learning progress, learning improvement, development of self-efficacy, self-assessment, use of mistakes as opportunities for learning. The view of formative assessment employed belongs to Royce D. Sadler.
\end{abstract}

Keywords: feedback, formative assessment, learning progress, learning to learn.

\section{Rezumat}

Articolul se doreşte a fi o pledoarie pentru folosirea evaluării formative - cu eviden ierea rolului atribuit feedback-ului în acest proces - în vederea dezvoltării învă ării elevilor, inclusiv a competen ei de a învă a să înve $i$. Avem în vedere, în special, următoarele aspecte aferente ,vizibilizării” învă ării (în sensul de explicitare, conştientizare, evaluare a progresului): scopuri/obiective, criterii de succes/reuşită, evaluare a progresului în învă are, îmbunătă ire a învă ării,

* Senior Researcher, Institute of Educational Sciences Bucharest, Romania. 
dezvoltare a auto-eficacită ii în învă are, auto-evaluare, folosire a greşelilor ca oportunită i pentru învă are. Viziunea asupra evaluării formative folosită în cadrul prezentului articol îi apar ine lui Royce D. Sadler.

Cuvinte-cheie: a învă a să înve i, evaluare formativă, feedback, progres în învă are.

\section{Introduction}

The article is a plea for the use of formative assessment in order to develop students' learning, including Learning to learn competence (from here on, we will use L2L to name it). The premise we are leaving from is that learning development is being accomplished only with the active engagement of the student and that it is made possible by making learning visible. This means that students can see their learning happening within the learning process. This visibility of learning is made possible through the ongoing collaboration between teacher and student and it is based on a continuous process composed of diagnosis, intervention and impact assessment, each feeding the others (Hattie, 2015).

Formative assessment has the potential to be the link connecting the abovementioned components, by being, at the same time, instruction and learning, the medium being detailed, quality feedback (written and oral form), expressed in a narrative form. Feedback brings forward content for guiding the intervention based on results of diagnosis and also offers guidance and direction for the impact assessment, in order to make learning visible, both for the student and teacher. The feedback addresses various topics related to student learning, such as: weak and strong points; suggestions for correction and for learning strategies; tips regarding how to better understand learning tasks and how to address them in an efficacious manner; causes of mistakes and how to correct them; perceptions, attitudes and beliefs about self and about learning and school; knowledge/skills gaps, etc.

So, within the process of formative assessment, the teacher scaffolds the learning process, searching for evidences related to learning mastery; gradually, through the use of feedback, the teacher details the results of the assessment to the student, in order to make him aware of the learning progress 
and to own the learning process.

Both feedback and formative assessment offer answers to these three questions regarding the learning progress: Where am I going?, Where am I now?, and What do I do next?.

The formative assessment perspective that we use belongs to Royce D. Sadler (1989) and has as main steps three topics: operationalization of referents/standards for learning goals; measurement of learning progress as reduction of gap/discrepancy between a certain level of learning performance and the reference one and mobilization of feedback and specific learning actions employed in order to reduce the above-mentioned gap. Once internalized and transformed into current practice, the use of formative assessment results guides the student learning towards L2L enabling/ empowering through regulation of their own learning.

\section{Definition of main concepts}

According to the EU definition, $L 2 L$ is

"the ability to pursue and persist in learning, to organize one's own learning, including through effective management of time and information, both individually and in groups. This competence includes awareness of one's learning process and needs, identifying available opportunities, and the ability to overcome obstacles in order to learn successfully. This competence means gaining, processing and assimilating new knowledge and skill as well as seeking and making use of guidance. Learning to learn engages learners to build on prior learning and life experiences in order to use and apply knowledge and skills in a variety of contexts: at home, at work, in education and training" (Definition of Learning to learn, in Education Council, 2006, para. 5, annex).

The same source mentions also that motivation and confidence are crucial to an individual's L2L competence.

Formative assessment is a continuous process, which is a constant companion of the instruction process and which has as main aim the development of 
learning by orienting and guiding it and by making it visible, explicit. It is a process of evidence gathering about the students' learning progress and of bringing this knowledge back to the students, through feedback. Besides the awareness role, the formative assessment has the scope of guiding the instruction in such a way to meet the students learning needs and to make them regulators of their own learning. Using the evidence gathered, the teacher can assess the students' learning progress and can make specific adjustments of teaching activities in order to improve it. As Sadler (1989, p. 120) says, "formative assessment is concerned with how judgments about the quality of student responses (performances, pieces, or works) can be used to shape and improve the student's competence by short-circuiting the randomness and inefficiency of trial-and-error learning".

According to the review done on formative assessment by Black \& Wiliam (1998), "it is to be interpreted as encompassing all those activities undertaken by teachers, and/or by their students, which provide information to be used as feedback to modify the teaching and learning activities in which they are engaged" (Black \& Wiliam, 1998, p. 7). Unlike normative assessment, based on comparison between students' grades - grading on a curve -, the formative assessment is focused on learning development, on guiding the students in becoming skilful in their own learning - using a criterion approach to assessment. The accent is put not on performance and comparison between students, but on learning mastery, i.e. development of learning for each student (Black \& Wiliam, 1998).

Feedback is information based on evidences gathered by teachers and the students themselves regarding learning progress and made available, in a detailed and timely manner, to students, in order to inform, guide and improve their learning. It deals with learning content, learning objectives, learning strategies, knowledge and/or skills gaps, next steps in learning, reflection on own learning, correction of mistakes, misunderstandings, etc. It deals with diagnosis, intervention and assessment of impact (learning progress). Its role is to scaffold learning, by gradually making the student more engaged in its own learning and able and willing to regulate own learning, based on evidence. Feedback is a key element in formative assessment and is usually defined in terms of information about how successfully something has been or is being done. Most learning skills cannot be acquired satisfactorily simply 
through being told about them. Their acquisition requires practice in which received feedback is embedded. In order to guide such practice, the teacher serves as a model, being a person which knows the skills to be learned, who can recognize, describe/be explicit and demonstrate a good performance (of learning). Also, such a teacher can also provide information and practical guidance about the improvement of performance. Feedback has as main role the reduction of the gap (discrepancy) between the present level and the target level within the learning process (and progress) (Sadler, 1989).

\section{Feedback - role, use, content, formulation}

We will use the definition of feedback as information provided by the teacher regarding aspects of students' performance and/or understanding (Hattie \& Timperley, 2007). Gradually, through the modelling (examples, guidance, instructions, detailing of assessment and success criteria) offered by teachers, the students themselves can become active and effective in self-monitoring their own learning. So, feedback has two audiences: teachers and students. It is made and used by teachers to make decisions with respect to readiness, diagnosis and remediation of students' learning. Students use it to monitor the strengths and weaknesses of their performances, so that aspects associated with success or high quality can be recognized and reinforced, and unsatisfactory aspects modified or improved (Sadler, 1989).

One of the most important defining characteristic of feedback is that it is used, actively, in order to reduce the gap between actual learning performances and a specific learning objective or target (Ramaprasad, 1983, as cited in Sadler, 1989). According to Sadler, for a student to be a learner, he has to:

"(a) possess a concept of the standard (or goal, or reference level) being aimed for, (b) compare the actual (or current) level of performance with the standard, and (c) engage in appropriate action which leads to some closure of the gap." (Sadler, 1989, p. 121).

We will present more information regarding this topic in the section dedicated to the design of the learning environment. 
If we think about learning as a process, we see it as a road taken towards reaching certain learning objectives, from the point of where he does not yet know (enough or at a certain level of performance) to the point where he knows (at a certain level of proficiency/performance). This means that, as the students progress towards the objectives, the distance reduces. They can, gradually, learn to appreciate the distance left and the strategies they can employ in order to cover it. It is, in a way, a process of owning the learning process, just like a carpenter that has to build a rooftop for the house. He knows what tools are needed, how to use them in an effective manner and how to dose the working effort daily to reach the deadline. The role of feedback is to guide the student in how to reach the distance to the destination (learning objectives): which strategies to employ, which topics/ issues he does not yet know, how to understand those, how to build new information on the one already known, how to support themselves in this process (both emotionally and cognitive), how to learn information necessary to correct errors, how to identify and cope with debilitating beliefs about learning (cannot do it, incapable of doing it, lacking skills in order to do it, not having ability for it, etc.), how to harness the strong points and to improve the weaker ones, how to make sure he understands and solves learning tasks correctly.

Along the learning road, the students meet different roadblocks that they have to overcome in order to advance toward their goals/objectives. These obstacles might reside within the learning activities themselves - harder topics, difficult exercises - or/and in the students' mind - such as "I cannot solve it", "I do not have what it takes to learn math", "I am not a language learner kind of person" and so on. A proper feedback has to identify not only the difficulties met by the student when dealing with learning topics and exercises, homework, but also with those hardships met when he approaches a learning task: type of self-talk, self-criticism, self-image as a student, pessimism or optimism, confidence in his own learning success, etc. All these aspects are usually harder to be noticed, as they reside in the back of the students' minds, lurking. They can have either a positive or a negative contribution to the student's learning, depending on how are dealt with by the students themselves. Once such aspects are brought to light, there are increased chances for making them visible, such that they can be addressed directly, through a conscious approach. 
Our view on the proper use of feedback in education is, to quote J. Hattie, "make learning visible". It is, to put it figuratively, as if you take out the contents of the students' minds during learning and make them pay attention and recognize them. In such a way, the students become aware of what goes on in their minds during learning, increasing their chances to better adapt to different learning situations, in order to improve learning.

Feedback has multiple roles within the learning process, as it guides diagnosis, intervention and impact. It informs each of these stages of the process of learning improvement, by locating the gradual positioning of each student on the way to reaching learning objectives, by offering information on the steps needed to advance and also on the assessment of advancement, of the measure in which the targets are reached. Each point reached by the students on their learning roads is relevant in terms of learning gains, of what is already known and what else must be learned in order to reach the next point. It is like taking the pulse of learning, to see at what state the student is and which are the next steps to be taken (Hattie \& Timperley, 2007).

Beyond developing students' L2L competency, feedback is a way of empowering them, transferring a lot of the power from the teacher towards the student. The teacher loses a lot from his position of knowledge assessor, validator, becoming a sustainer, facilitator of learning, allowing the student to become the master of his own learning.

The main supposition which is guiding our approach is that, once the student develops L2L competence, he will use it as a starting point in a variety of subjects and learning activities. We view learning as a process. By this we mean that, at any moment in time during learning, there is not a certain level of L2L competence set in stone, fixed, but a continuous development, a slower or faster one. Beyond giving feedback, the teacher has to offer opportunities for students so that they show/put to work how they understand and use feedback in order to improve their learning. What this means is that, following assessment, students are requested to remake the exercise or do a very similar one, so that the teacher can see if they understood and addressed the previous mistakes or weak points. This approach has a double value: offers opportunities for improvement through feedback incorporation and shows to the student how to connect the feedback received with certain 
standards set for task accomplishment - the criteria which must be met in order to reach a certain learning standard/goal.

As Black \& Wiliam show in their review on formative assessment (1998), the effectiveness of formative work depends on the content of the feedback and corresponding learning opportunities offered by the teacher, and on the context of attributions about the motivations and self-perceptions of students within which are taking place. Feedback which is directed to the students' learning needs and objectives, constructed on the belief that each student can and will succeed, has a more empowering effect than the one which refers/provides comparison with peers. The latter one is, often, based on "the assumption - albeit covert - that some students are not as able as others and so cannot expect full success" (Black \& Wiliam, 1989, p. 17).

As Sadler (1989), Troy (2014), Hattie \& Timperley (2007), Black \& Wiliam (1998) show, formative assessment makes a difference, and it is the quality, not just the quantity, of feedback that merits our closest attention. By quality of feedback, we have to understand not just the technical structure of the feedback (aspects of its accuracy, comprehensiveness and appropriateness) but also its accessibility to the learner (as communication, comprehension), its catalytic and coaching value, and its ability to inspire confidence and hope. For a feedback to be efficient, it is necessary to meet certain characteristics, such as:

- To be addressed as soon as the learning activity happened;

- To address not only the mistakes made by the student, but also what he has done well; the aim of feedback is to facilitate student's learning development, not to punish or put him into defensive;

- To address the learning behaviour/action, not the person of the student; the aim of the feedback is to inspire and support development, change of learning for the better, so it should target learning activities, attitudes, beliefs, not the person itself;

- To be detailed, explicit, bringing forward causes for mistakes, arguments for good work, suggestions for corrections or for the use of different approaches, learning strategies;

- To be addressed in a constructive manner, bringing forward suggestions regarding what the student could do to correct mistakes, improve learning, self-monitor, etc., instead of reproaching mistakes and offer (negative) 
suggestions such as "do not do this; this is wrong; you are mistaken";

- To propose viable behaviour change, learning strategies, etc.;

- To be addressed in a non-judgmental form, without attacking the student;

- To be formulated as a suggestion, proposal for the student to consider, not as an obligation to submit compliance to; behaviour control from teacher to student might backfire, and could result in sabotage and/or insubordination, refusal to be addressed/accepted;

- To be addressed highlighting how it can contribute to the student learning development and not engage in comparisons with other students; the aim is not to induce competition between students, but to focus on mastery of learning, including through the use of cooperation, collaboration, peerassessment;

- To be addressed with a focus on progress towards the learning goals and be detailed taking as reference the success criteria for learning performance;

- To be addressed as revealing an image of learning performance as a point/moment within the larger process of learning, so as to focus the student's attention on change, malleability, not on fixity;

- To induce the idea of improvement through error correction, revising of learning tasks, use of feedback to improve learning.

Also, in order to be better understood, accepted and used by the students, the feedback needs to offer detailed, quality information regarding topics such as (Sadler, 1989; Troy, 2014; Hattie \& Timperley, 2007; Black \& Wiliam, 1998):

- What the student has done well, correct and what has done wrong and to bring forward reasons, arguments in support;

- What the student might do to correct what he has done wrong, what strategies he might use to improve learning;

- What the student has improved regarding both a previous moment of assessment and in the direction of reaching his learning goals (as set by the reference criteria established together with the teacher);

- Learning opportunities and resources that might be used to improve learning;

- Bringing forward the progress in student learning, so that his confidence and efficacy in learning to be addressed and improved; 
- The next steps that the student might take in his learning in order to guide him towards the learning goals;

- Use of learning opportunities in order to address, revise learning, including mistakes made;

- Reflection on the student's own learning, regarding strategies, affective state, personal beliefs and attitudes, etc.;

- The formative use of peer assessment as a way to gather and share information in a constructive manner.

\section{Design of learning environment in order to facilitate formative assessment}

In this section, we detail some of the aspects related to the process of making students become learners. We will focus our attention on the three aspects established by Sadler (1989) as fundamental: standards or referents for learning (as goals, direction that guides learning); comparison between a certain point in the learning process and the goals established (as measurement of learning progress) and engagement in action to close the gap between the two reference points (incorporation of feedback in order to improve learning progress/reduce the gap). Also, we will accentuate the role that must be given to allowing mistakes in the learning process and their use as learning opportunities.

\subsection{Standards/referents for learning}

According to Sadler (1989), a standard or reference level is a designated degree of performance which serves as a benchmark for assessment of learning progress. The reference level becomes a goal when "it is desired, aimed for, or aspired to" by the students (Sadler, 1989, p. 129). Some goals are external (assigned by a teacher) while others are developed or adapted by the learners themselves. If a learner decides to ignore or reject an external goal, then it is likely to have little if any effect on achievement (except in a coercive situation). If the learner assumes ownership (acceptance, commitment) of a learning goal than it can play an important role within the regulation of performance. 
Sadler says that research (in field and laboratory settings), has shown that "hard goals" have the greatest impact on performance. These are defined as being specific and clear (rather than general or vague), harder and challenging (rather than simple or easy), and closer to the upper limit of an individual's capacity to perform than to the current level of performance. They "act to focus attention, mobilize effort, and increase persistence at a task" (p. 129). Do-one's-best goals are shown to be not much more effective than no goals at all.

Sadler warns that if the expectations regarding the student's learning progress are established higher or faster than his own pace in progress, the consequence will be, on the student's part, a perception of inability and "little or no sense of accomplishment even though improvement may actually be occurring" (p. 130). This may lead to a situation where successive learning attempts are taken less seriously, where the performance gap (between the present and the target level) widens progressively and becomes selfreinforcing (e.g. becoming a clue, 'prove" of a certain lack of skills in learning), and where the student loses motivation and, eventually, even drops out.

In some subjects, says Sadler:

"the different rungs of the ladder of achievement take the form of a gradation in both scope and complexity; in others, they reflect different standards on a well-defined quality dimension. In classroom settings, students may need access to a range of standards (not just the top rung) to cater for different abilities" (Sadler, 1989, p. 130).

If the learner perceives the gap between his current status and the aspiration (the one made visible by the reference level) as too large, the goal may be perceived or regarded as unattainable and he may disengage from learning or lower the goal. The same gap may provide a powerful stimulus for another student - highly motivated and confident, who would not be put off by a sequence of initial failures. Here, as we see, it is important to have information regarding the student confidence and motivation in/for his own learning, as these factors might mediate the effort, persistence and use of learning strategies that he employs in his learning. Conversely, if the gap is perceived as too small, closing it might be considered not worth any additional effort. 
Initially, the teacher may find it useful to negotiate the aspiration level with the student, or at least to take individual student characteristics into account. The aim, says Sadler, should be to have the student set, internalize and adopt the goal, so that there is at least some determination (engagement, motivation, effort, etc.) to reach it.

\subsection{Measurement of learning progress}

In addition to knowing about appropriate standards, students have to be able to compare their actual levels of performance with these standards. This requires that they are "capable not only of making multicriterion judgments about their own work but also of making them with a proper degree of objectivity and detachment" (Sadler, 1989, p. 130). In order to do this evaluative appreciation of their progress in learning, they need to have at their disposal specific criteria - qualitative descriptors, detailing each level of performance within the learning standards. One way to do the measurement is to identify what amount of progress/ accomplishment has been reached on each composing criterion and then to make a global (additive) assessment. The teacher may have as criteria for a composition assessment such aspects as: fluency; vocabulary; syntax; use of arguments and/or evidence; description of characters; use of imagination; realism; logical organization of material; use of proper forms of composition; use of dialogue; use of different meanings; relationship between context and description; coherence of the presentation, and so on. Or, in case of assessment criteria for natural sciences and/or mathematics, the teacher might use such aspects as: understanding of concepts and their definitions; using algorithms for solving tasks; using working hypotheses to reach results; use of mathematical operations; use of concepts learned in other subjects; understanding of relationships between phenomena; use of evidence for proving results; use of demonstration; checking of the correctness of results/algorithm, etc.

In order to offer formative assessment, the teacher must give detailed qualitative feedback to the students, in such a way that they can connect it to the learning progress/reduction of the gap between their present level and the learning goal. This feedback may take multiple forms, such as written and verbal and can be used for a lot of learning activities: homework, 
classroom activities, portfolio products, essays, exercises in front of the class or at individual/group level, tests, etc. Also, the detailed feedback should be accompanied by the detailed presentation of the assessment criteria, so that the students know firsthand which the success criteria for reaching certain performance levels are. The detailed, narrative information offered by the teacher through feedback has the role to connect assessment criteria to the assessment of the students' level of progress in such a way that assessment results are used and incorporated by students to better address their learning improvements. As Sadler says, certain criteria are hard to be understood without a specific example.

"Criteria often seem elusive partly because what a criterion means and what it implies for appraisal cannot necessarily be defined in isolation from concrete examples of things which possess the property in question, which in any case is usually only one of many properties. Coming to an understanding of the property is therefore as much an epistemological as it is a technical matter. To clarify the meaning and implications of a particular criterion, it would be useful to have a set of graded examples exhibiting more or less of that property" (Sadler, 1989, p. 135).

4.3. Engagement in action to close the gap between a certain earning level and the goal(s)

Students can reduce the gap separating their present level of learning from the goals by using the feedback received from teachers and colleagues. By revising, refining, reflecting on their learning products (exercises, essays, compositions, projects, etc.), students get a better, and more intimate knowledge of quality criteria and can put them into practice, in order to improve their own learning. Also, in the peer or teacher reviewing process, they get a sense of what is on track and what not and can use the suggestions and clarification requests received in order to create a sort of pool of practical knowledge and strategies for improvement. Through the process of peer reviewing, the students practice in becoming more engaged, more attentive, more reflective and may increase the appropriation of constructive criticism, close reading, writing and re-writing. Making use of cooperative learning activities might be a very good choice for a teacher in order to put to good and constructive use the evaluative assessment of the students themselves, 
using, of course, clearly specified standards regarding quality criteria predefined for the different learning goals. Through a process of learning tasks revision following feedback, the students gain a chance to show how much they understood and used it in order to improve their knowledge and skills compared with those from a previous moment of the formative assessment. They can expect improvement if the feedback was understood and embedded in the task revision and we expect that their confidence in their learning ability will increase, as their motivation to improve learning. This is a sort of forward feeding feedback, which feeds the next steps the student is taking in learning.

Sadler, among others, brings into the open a possible resistance on the teacher's part, regarding their previous monopoly on assessment, especially the summative one:

"Some teachers feel threatened by the idea that students should engage openly and cooperatively in making evaluative judgments. An assessment which results in a grade is used by many teachers as a tool for the control or modification of behavior, for rewards and punishments. To remove some of the responsibility for assessment from teachers and place it in the hands of students may be considered to have the potential for undermining the teacher's authority. A less pathological concern is that many teachers perceive evaluation as the responsibility primarily of teachers because it constitutes part of the specialized knowledge and expertise that they have acquired as professionals. Assessment is regarded as strictly the teachers' prerogative: it sets them apart from their students and to some extent from parents and the rest of society" (Sadler, 1989, p. 141).

\subsection{Mistakes as learning opportunities}

In order to maximize the constructive role of feedback for students' learning, the teachers should create a learning environment (e.g. classroom) that is facilitating learning, questioning, curiosity, interest and is allowing mistakes as opportunities for learning. Mistakes, as some of the roadblocks that the students meet on the learning road, are quite important. On one hand, they show what the student does not yet know / solve / understand and, on the 
other hand, they prompt different behaviours, beliefs, emotions on the students' part. Mistakes can be seen as very important opportunities for making learning visible. If we think a little about mistakes during learning, we realize each one of us has done quite a few mistakes; if they are targeted as learning opportunities, then the negative pressure to hide them from yourself and others is reduced/kept under control and your attention can be better directed for understanding what caused the mistake and how can you correct it. Mistakes are, in our opinion, a springboard for learning. Therefore, it is important to create a learning environment that encourages learning, is mistake-friendly (other students and teacher do not laugh or make fun about mistakes, but use them to understand, deepen learning, address personal insecurities), encourages information exchange and search, uses questioning as a starting point and so on.

\section{Conclusion}

The main idea of the present article is that, in order that students become lifelong learners, possessing L2L competences, they need to become, gradually, owners, producers and assessors of their learning. The formative assessment plays a powerful role in this direction, by making possible a continuous development of students' learning, including the knowledge and skills of learning assessment and improvement through feedback incorporation. The process of the use of formative assessment for the transitioning of the subject (and object) of assessment from the teacher to the student is, in many regards, similar to one of mentoring induction in selfassessment as a method to develop your own learning. One of the most important condition for learning improvement is

"that the student comes to hold a concept of quality roughly similar to that held by the teacher, is able to monitor continuously the quality of what is being produced during the act of production itself, and has a repertoire of alternative moves or strategies from which to draw at any given point. In other words, students have to be able to judge the quality of what they are producing and be able to regulate what they are doing during the doing of it" (Sadler, 1989, p. 121). 


\section{References}

- Black, P., \& Wiliam, D. (1998). Assessment and Classroom Learning. Assessment in Education: Principles, Policy \& Practice, 5(1), 7-74. https://doi.org/10.1080/ 0969595980050102.

- Hattie, J., \& Timperley, H. (2007). The power of feedback. Review of Educational Research, 77(1), 81-112. https://doi.org/10.3102 003465430298487.

- Hattie, J. (2015). What Works Best in Education: The Politics of Collaborative Expertise, London: Pearson. Retrieved from https://www.pearson.com/content/ dam/one-dot-com/one-dot-com/global/standalone/hattie/files/150526_ ExpertiseWEB_V1.pdf.

- Heritage, M. (2014). Formative assessment: an enabler of learning. Retrieved from http://www.amplify.com/assets/regional/Heritage_FA.pdf.

- Hicks, T. (2014, October 14). Make It Count: Providing Feedback as Formative Assessment. Retrieved from https://www.edutopia.org/blog/providing-feedbackas-formative-assessment-troy-hicks.

- Oosterhof, A. (2014). Using feedback with formative assessments. Retrieved from http://www.cala.fsu.edu/modules/assessment_feedback/\#page $=1$.

- Sadler, D. R. (1989). Formative assessment and the design of instructional systems. Instructional Science, 18(2), 119-144. https://doi.org/10.1007/ BF00117714.

- William, D. (2011). What is assessment for learning?. Studies in Educational Evaluation, 37(1), 3-14. Retrieved from https://www.sciencedirect.com/ science/article/pii/S0191491X11000149.

- Wilson, A. (2012, March). Student engagement and the role of feedback in learning. Retrieved from https://www.beds.ac.uk/jpd/volume-2-issue-1/studentengagement-and-the-role-of-feedback-in-learning.

- Recommendation of the European Parliament and of the Council of 18 December 2006 on key competences for lifelong learning (2006/962/EC). Retrieved from https://eur-lex.europa.eu/legal-content/EN/TXT/PDF/? uri= CELEX:32006H0962\&from $=E N$. 
The online version of this article can be found at: http://revped.ise.ro/category/2018-en/

\section{(cc) $\mathrm{BY}-\mathrm{NC}-\mathrm{SA}$}

This work is licensed under the Creative Commons Attribution-NonCommercial-ShareAlike 4.0 International License.

To view a copy of this license, visithttp://creativecommons.org/licenses/by-ncsa/4.0/ or send a letter to Creative Commons, PO Box 1866, Mountain View, CA 94042, USA.
Versiunea online a acestui articol poate fi găsită la:http://revped.ise.ro/category/2018-ro/

\section{$( c c ) \longdiv { B Y - N C - S A }$}

Această lucrare este licen iată sub Creative Commons Attribution-NonCommercial-ShareAlike 4.0 International License.

Pentru a vedea o copie a acestei licen e, vizita $i$ http://creativecommons.org/licenses/by-nc-sa/4.0/ sau trimite i o scrisoare către Creative Commons, PO Box 1866, Mountain View, CA 94042, SUA. 